\title{
The Interplay Between Landscape Structure and Biotic Interactions
}

\author{
Phoebe L. Zarnetske ${ }^{1,2,3} \cdot$ Benjamin Baiser ${ }^{4} \cdot$ Angela Strecker $^{5} \cdot$ Sydne Record $^{6}$ • \\ Jonathan Belmaker $^{7} \cdot$ Mao-Ning Tuanmu ${ }^{8}$
}

Published online: 24 February 2017

(C) Springer International Publishing AG 2017

\begin{abstract}
Landscape structure and biotic interactions are closely linked. We identify five aspects of landscape structure that contribute to the co-occurrence of species and restrict or enable different types of biotic interactions: patch size and habitat amount, isolation of patches, barriers to dispersal and movement, persistence of landscape structure, and landscape complexity. In addition, these aspects of landscape structure influence the strength and outcome of biotic interactions. Whereas most research focuses on the effects of the abiotic environment on species and their biotic interactions, research on foundation species and ecosystem engineers demonstrates the important influence of biotic interactions on landscape structure itself, including effects on landscape complexity, extent of habitat, and the structure of landscape features. In this review, we describe ecological theories that lay the foundation for interplay between landscape structure and
\end{abstract}

This article is part of the Topical Collection on Effects of Landscape Structure on Conservation of Species and Biodiversity

Phoebe L. Zarnetske

plz@anr.msu.edu

Benjamin Baiser

bbaiser@ufl.edu

Angela Strecker

strecker@pdx.edu

Sydne Record

srecord@brynmawr.edu

Jonathan Belmaker

jbelmaker@post.tau.ac.il

Mao-Ning Tuanmu

mntuanmu@gate.sinica.edu.tw

1 Department of Forestry, Michigan State University, 480 Wilson Rd, East Lansing, MI 48864, USA biotic interactions, and summarize these connections across an array of interacting species in freshwater, marine, and terrestrial systems. We end with suggestions for integrating the fields of landscape ecology and community ecology to better understand the connections between landscape structure and biotic interactions and better predict their dynamics in light of global change.

Keywords Biotic interactions $\cdot$ Dispersal $\cdot$ Extent $\cdot$ Habitat . Isolation $\cdot$ Metacommunity

\section{Introduction}

Biotic interactions are inherently coupled with the structure of landscapes. "Landscape structure" encompasses the

2 Department of Fisheries \& Wildlife, Michigan State University, 480 Wilson Rd, East Lansing, MI 48864, USA

3 Ecology, Evolutionary Biology, and Behavior Program, Michigan State University, 480 Wilson Rd, East Lansing, MI 48864, USA

4 Department of Wildlife Ecology and Conservation, University of Florida, 110 Newins-Ziegler Hall, Gainesville, FL 32611, USA

5 Department of Environmental Science and Management, Portland State University, P.O. Box 751, Portland, OR 97201, USA

6 Department of Biology, Bryn Mawr College, 101 North Merion Ave, Bryn Mawr, PA 19010, USA

7 School of Zoology and The Steinhardt Museum of Natural History and National Research Center, Tel Aviv University, Tel Aviv 69978, Israel

8 Biodiversity Research Center, Academia Sinica, Taipei 115, Taiwan 
composition and spatial arrangement of natural and anthropogenic features over time. Components of landscape structure - patch size and habitat amount, isolation of patches, barriers to dispersal and movement, persistence of landscape structure, and landscape complexity - interact with ecosystem components. The resultant interactions directly affect species' habitat quality and species-habitat relationships, as well as species co-occurrence. Consequently, landscape structure influences whether species can interact with one another, and thus affects species abundances and traits, which affect the strength of biotic interactions. In turn, biotic interactions also influence landscape structure [1]. Interactions involving ecosystem engineers and foundation species change landscape structure and function in both space and time [2, 3]. At the same time, the dynamic nature of these landscapes is influenced by abiotic and anthropogenic forces [4, 5]. Depending on spatial and temporal scales, landscape structure can affect the occurrence, importance, and outcomes of biotic interactions differently [6-8], and biotic interactions can have varying influence on landscape structure [3, 5, 9].

Here we use "landscape" to encompass terrestrial, marine, and freshwater "scapes" on earth. The movement of organisms, energy, and matter within and among ecosystems of all types is highly dependent on the structure of a landscape. Such structure is often used to define aspects of species-habitat relationships including range sizes and associated physiological limits to occurrence, habitat patch size and speciesspecific connectivity, and physical barriers to dispersal. For fauna and flora, landscape structure affects aspects of movement that are fundamental to species' fitness and survival, including dispersal, migration, and mobility.

We present a synthesis of the connections between landscape structure and biotic interactions, with a focus on studies from the last 10 years. We begin with a discussion of relevant theory and then discuss how landscape structure affects biotic interactions, and how biotic interactions can reciprocally affect landscape structure. We end with recommendations to advance understanding of this interplay, and promote synergy of community ecology and landscape ecology.

\section{Theory}

Several theories provide important context for understanding the connections between landscape structure and biotic interactions. We discuss three theories that have especially advanced understanding of this interplay: niche theory, the theory of island biogeography, and metacommunity theory.

One of the first examples of the interplay between landscape structure and biotic interactions is found in niche theory. The Grinnellian and Eltonian niche concepts describe the effect of the environment on a species occurrence [10], and the effect of a species on its environment [11]. The niche concept was further defined in terms of biotic interactions and landscape structure in Hutchinson's realized niche (see [12] where "biotop space" refers to landscape structure). Hutchinson's realized niche represents the conditions for the occurrence and positive population growth rate of a species as a function of its habitat (including landscape structure) and biotic interactions $[12,13]$. Originally, the realized niche was described as a function of competition reducing the occurrence of a species to its realized niche from its fundamental niche, but now other types of interactions (positive interactions) are also recognized as affecting the realized niche [14] and could even expand it beyond the fundamental niche [15]. Today, niche theory is widely applied in species distribution modeling $[16,17]$, yet such models focus largely on abiotic drivers and rarely explicitly model pairwise or multi-species interaction relationships [18-20].

Another classic foundational theory that incorporates landscape structure and biotic interactions and largely stimulated the fields of landscape and spatial ecology is the theory of island biogeography [21]. The theory of island biogeography explores colonization and extinction dynamics of island communities as a function of island size and distance from mainland. The theory was first tested in mangrove islets [22] and has since been applied to "islands" in a broad sense to understand the assembly, maintenance, and disassembly of ecological communities in naturally patchy habitat islands (e.g., [23]), habitat islands created through fragmentation (e.g., [24]) and habitat loss [25], and preserves that can be considered islands in a sea of unconserved land [26].

The theory of island biogeography is a neutral theory that does not explicitly consider biotic interactions. Biological rates of birth, death, and migration are assumed to be identical across species and thus are influenced equally by interactions with other species. Initial consideration of trophic interactions in an island biogeographical context [27] and recent extensions of the theory of island biogeography that include trophic interactions $[28,29]$ have led to a better fit of the island biogeography model to empirical data. A trophic analysis of a classic island biogeography experiment on recolonization following defaunation [22] showed that generalist species tend to colonize first whereas specialists arrive later in the assembly process [30]. Including both mutualistic and competitive interactions in island biogeography models will likely yield more insight into the processes structuring ecological communities. The improved predictions resulting from the inclusion of biotic interactions into the theory of island biogeography signal the importance of biotic interactions at the landscape scale.

A more recent theory that has strongly influenced how ecologists think about diversity at the landscape scale is metacommunity theory [6]. Metacommunity theory explores the roles that biotic interactions, local-scale environmental conditions, and regional-scale dispersal play in determining 
community structure. Whereas the majority of theoretical and empirical studies on metacommunities focus on competition as the biotic interaction of interest [31], trophic interactions (e.g., [32-34]) and mutualistic interactions (e.g., [35]) have also been explored. By considering both local and regional scale processes, metacommunity theory implicitly incorporates landscape structure.

To understand the connection between landscape structure and biotic interactions in a metacommunity framework, it is first necessary to understand the underlying metacommunity dynamics appropriate for the system under study. In general, metacommunities can be separated into four general models that describe the processes underlying spatial patterns in diversity and community assembly: the patch-dynamics, species-sorting, mass effects, and neutral models [6].

The patch-dynamics model assumes that (1) all patches are intrinsically equal and capable of maintaining populations of any species in the regional species pool (i.e., no environmental filter), (2) there is a trade-off between dispersal and competitive abilities, and (3) local population dynamics (i.e., births and deaths) occur at a faster time scale than regional dynamics (i.e., dispersal) [6]. The key metacommunity processes structuring local communities under the patch-dynamics model are dispersal and biotic interactions. Species that are poor at establishing (e.g., inferior competitors, vulnerable prey) have higher dispersal rates than their competitive dominants and predators allowing them to colonize "open" patches, thus maintaining biodiversity across the landscape. This trade-off between competitive ability or vulnerability to predation (i.e., biotic interactions) and dispersal is central to this perspective (the competition-colonization trade-off) [6]. Any landscape factor (i.e., fragmentation, barriers, isolation) that alters this trade-off can drastically change biodiversity patterns at the landscape level (e.g., [36-39]).

The species-sorting model assumes that (1) habitat patches are different, (2) different species do well in different types of patches, and (3) local population dynamics occur on a shorter time scale than dispersal dynamics. Environmental filtering plays an important role in structuring communities under the species-sorting model by favoring certain species in the outcome of biotic interactions in certain habitat patches [40]. However, another stipulation of the species-sorting model is that dispersal is frequent enough for species to make it to patches where they are favored. Thus, any alteration of landscape structure that hampers dispersal may preclude species from reaching habitat patches where they can establish, reducing occupancy of such species and potentially leading to their extirpation from the landscape. As in the patch-dynamics model, landscape-induced dispersal limitation of dominant competitors or predators may allow for the establishment of inferior competitors or vulnerable prey.

The mass effects model is similar to species-sorting in that (1) patches are different and (2) different species do well in different types of patches. However, the important difference between mass effects and species-sorting is that dispersal occurs at a faster time scale than local population dynamics under the mass effects model. Dispersal is the most important process in the mass effects model. Under mass effects, species that are poor competitors or vulnerable prey in a given habitat patch can establish in less hospitable patches owing to rescue effects - the rescue of a sink population by individuals emigrating from a source population [41]. Since dispersal rate is the key difference between species-sorting and mass effects [31], landscape structure may be a key modifier in tipping metacommunity dynamics towards one or other model by either inhibiting or facilitating dispersal.

Under a neutral model $[42,43]$ all species are equivalent in their dispersal and competitive abilities, and in their birth and death rates. Community composition results from stochastic population processes and dispersal limitation. Landscape structure does not influence biotic interactions, simply because biotic interactions are considered unimportant. Although spatial structure is still a major factor limiting dispersal and hence influencing community composition, altering landscape structure will not cascade into influencing the interactions between species.

Until recently, empirical studies of metacommunites have not considered landscape structure explicitly $[44,45]$. Yet variation in dispersal rate among species in a metacommunity-a key component of metacommunity dynamics - can result from species' traits or structural aspects of the landscape (e.g., distance between patches, matrix structure, and arrangement of patches) [46]. Whereas metacommunity models include general variation in dispersal, few investigations (e.g., [47]) explore how dispersal is affected by both functional connectivity, i.e., the role of species traits and their interaction with the landscape, and structural connectivity, i.e., spatial configuration of landscape features [48]. As functional connectivity is a species-specific concept [49], considering it as such will likely better represent dispersal dynamics in metacommunities [45].

Another gap in integrating landscape structure into metacommunity theory is the absence of an underlying structural landscape model [47]. Explicit landscape models are necessary because dispersal through different landscape types [50] and the directionality of dispersal [51], which can be affected by landscape structure, can alter metacommunity structure and dynamics. Furthermore, the arrangement of quality patches $[52,53]$ or patch type - the environmental component of metacommunities-can also influence metacommunity dynamics. The arrangement of patch type may especially come into play when considering predatorprey interactions where predators require larger ranges with multiple habitat types and prey items occur only in a few of those habitat types.

Metacommunity studies also show that competitive interactions can be affected by landscape structure [45]. In 
simulation studies of metacommunities, increasing the number of suitable and available habitat patches, landscape heterogeneity, and the size of a metacommunity can all enable more chances for colonization events and lead to greater community monopolization [54] - the ability of a species to arrive to a new patch, establish, and evolve to monopolize resources and strongly compete with any conspecific immigrant [55]. Whereas these simulations were based on Tetragnatha spiders of Hawaii, the findings are applicable to other discrete, patchy communities [54]. Explicitly incorporating landscape structure into current metacommunity models provides an opportunity to create clear links between biotic interactions and landscape structure.

Metacommunity dynamics do not typically consider evolutionary responses of species to landscape structure. However, it is clear that the potential for local selection (e.g., for character displacement that may reduce competition [56]) will depend on gene flow and hence on landscape structure. Incorporating natural selection into models of metacommunity dynamics is a promising research direction that may further elucidate the effect of landscape structure on biotic interactions.

Different models have been used to describe the relationships between species and their habitat patches. At one end of the spectrum, the pattern-oriented, patch-corridor-matrix model of landscape structure [57] draws on the theory of island biogeography theory and emphasizes the importance of high quality patches (in contrast to surrounding matrix) for maintaining species. The model assumes that multiple species respond in the same way to landscape change $[58,59]$. At the other end of the spectrum, a species-oriented approach-the continuum model of landscape structure $[60,61]$ — posits that gradients better describe the boundaries between patches, corridors, and matrix. The continuum model of landscape structure assumes that species have individualistic responses to habitat fragmentation or habitat loss because species are distributed in space according to their specific requirements [58, 59]. An alternative "integrated community concept" [62] is more akin to the metacommunity concept because it recognizes the interdependence among species in their responses to habitat fragmentation [59].

The set of theories described above link landscape ecology and community ecology, yet there are still important theoretical connections to be made. Advancing theory that integrates these subfields of ecology could be achieved via simulation modeling [45], meta-analyses (e.g., [63]), and landscape-scale experiments (e.g., [64]).

\section{Recent Examples of How Landscape Structure Affects Biotic Interactions}

Here we outline five main aspects of landscape structure and describe their effects on biotic interactions. These aspects include patch size and habitat amount, isolation of patches, barriers to dispersal and movement, persistence of landscape structure, and landscape complexity (Fig. 1). Our review focuses on papers across freshwater, marine, and terrestrial systems within the last 10 years that incorporate biotic interactions in a landscape structure context. In July 2016, we searched Scopus for landscape structure terms that occurred in keywords, titles, and abstracts since 2005 (see Appendix). We then further selected papers within this set that had to contain one of the terms representing biotic interactions and/ or community ecology, in keywords, titles, and abstracts (see Appendix). From the resulting papers, we selected studies that would represent an array of ecosystem types and address each of the aspects of landscape structure. We include a condensed summary of paper findings across different ecosystems in Table 1.

\section{Patch Size and Habitat Amount}

Patch size, defined as the amount of habitat available for species in a single patch, and habitat amount, defined as the total amount of habitat available for species across all patches [97], can influence the type, frequency, and intensity of biotic interactions. For instance, interspecific competition among birds in tropical forests was most intense in small forest patches, but also varied in intensity depending on trophic specialization [98]. Interactions can also weaken with decreasing patch size. For example, in the tributaries of the upper Waimakariri River basin in New Zealand, a decrease in the amount of stream habitat aligned with a decline in the ratio of predator taxa to prey taxa, suggesting a weakening of predator control over prey [66]. In the South Fork Eel River in California, USA, interactions between aquatic invertebrate grazers and algae increased with drainage area, which represented complex factors such as resource availability, canopy cover, water temperature, stream size, and primary productivity [65]. In smaller drainages, invertebrates were unable to control algal growth, whereas invertebrates suppressed algae in larger drainages in part or all of the summer, reflecting greater top-down control by more diverse functional feeding groups in warmer, larger streams [65].

The relative amount of different habitat types can also affect biotic interactions. Burgett and Chase [38] found that the ratio of aquatic to terrestrial pond habitats can have different effects on the population sizes of amphibians that vary in life history strategies. Amphibian species with long-lived adults, which are more limited by demographic rates in terrestrial life stages, had lower within-pond population densities in the ponds with a higher aquatic to terrestrial ratio. As the larvae of one of the long-lived species (Ambystoma maculatum) are important predators in ponds, a change in their densities influenced community structure through changing predation intensity. 
Fig. 1 Five major types of landscape structures that interplay with biotic interactions. In each schematic, the dark gray and light gray shapes are distinct elements of landscape structure that interact with biotic interactions. For instance, the light gray habitat patches in $(b)$ indicate that patches that are relatively close together will have frequent dispersal between them (solid arrows), while isolated patches (dark gray) will only receive infrequent dispersal (dashed arrows), which can affect a number of important ecological interactions. The dashed lines in (c) indicate habitats that only persist for short periods of time (e.g., ephemeral habitats), in contrast to more permanent habitats (dark gray)

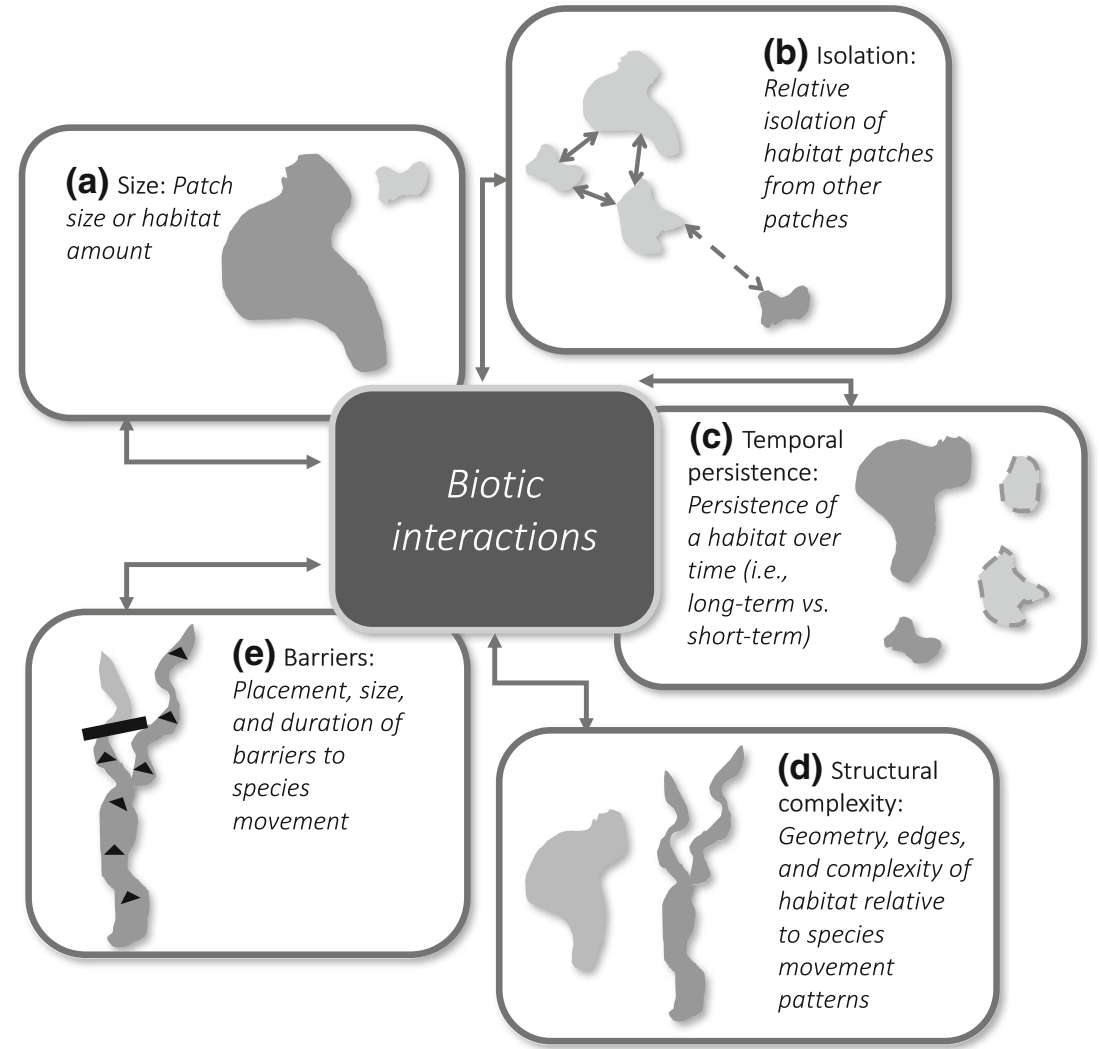

Although patch size and habitat proportions can affect biotic interaction strength, the total amount of habitat for some species may not affect the influence of biotic interactions on species' distributions. In a modeling study across the coterminous USA with woodpeckers and interacting birds, increasing the extent of habitat did not change the influence of biotic interactions on the distribution of woodpeckers, even though it changed the resolution of investigation [7].

In other studies, the effect of patch size on biotic interactions is often mediated by an aspect of community composition. In bromeliads in Central and South America, the relationship between predator to prey biomass ratios and patch size was dependent on the presence of the highly mobile odonates (i.e., predators), implying that species identity and traits can greatly influence species interactions [99]. In coral reefs, patch size can have different effects on biotic interactions and community composition. In French Polynesia's Moorea Island, there was no interaction between predators and patch size on measures of alpha- and beta-diversity for coral reef fish communities, suggesting that patch characteristics and topdown effects independently structure those coral reef fish assemblages [67]. In contrast, on the Shiraho Reef in Japan, the overall abundance of the four dominant and territorial herbivorous damselfish increased nearly linearly with reef patch log area, aligning with the species-area relationship [68]. However, although the damselfish density did not increase with reef patch area, it was higher on the largest reef patches; this was in contrast to the other 20 fish species whose density was inversely proportional to patch reef area. These findings suggest that herbivory and competition among territorial herbivorous damselfish may be stronger on larger reef patches, and that both territorial herbivores and patch reef area can structure reef community composition [68].

Studies of mutualistic relationships between plants and animals have yielded increasingly complex findings with regard to patch size and habitat amount. Sugiura [69] examined interactions of both native and exotic plants and ants on Japanese islands and found that the number of interactions increased significantly with increasing island area when all species were considered. However, network connectance (the proportion of possible interactions between species that are realized) and nestedness (a proxy of asymmetric specialization, where generalists interact with each other and specialists interact only with generalists) both decreased with island area [69]. Similar results were observed in a meta-analysis of plant-pollinator networks, where increasing study area size (i.e., habitat amount) positively correlated with the number of interactions, but negatively correlated with nestedness [70]. In plant-pollinator networks, a non-random loss of interactions with decreasing patch size was hypothesized to be related to how frequently the interaction was observed across the entire range and how often generalist species were involved in the interaction [100]. Experiments 


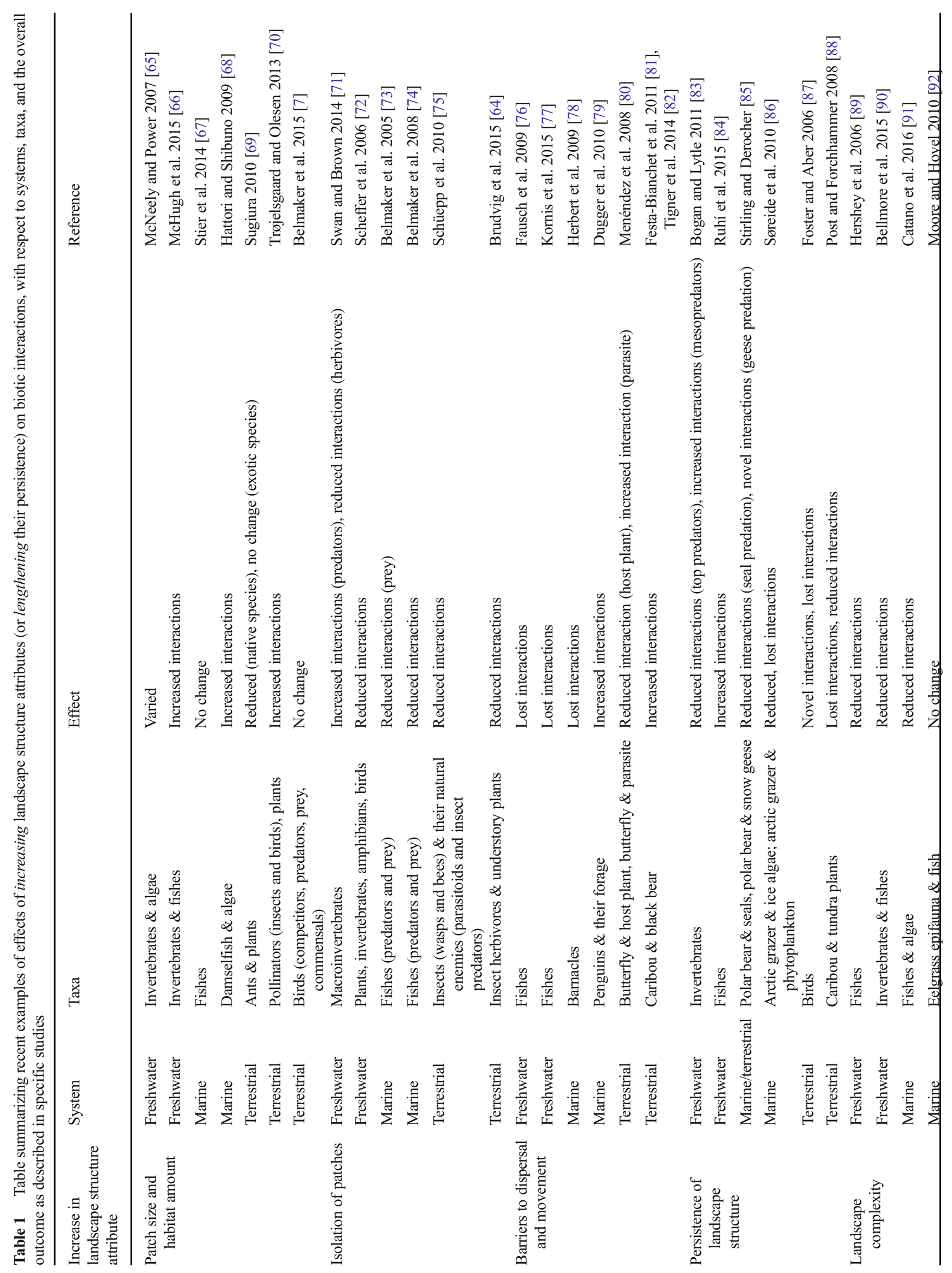




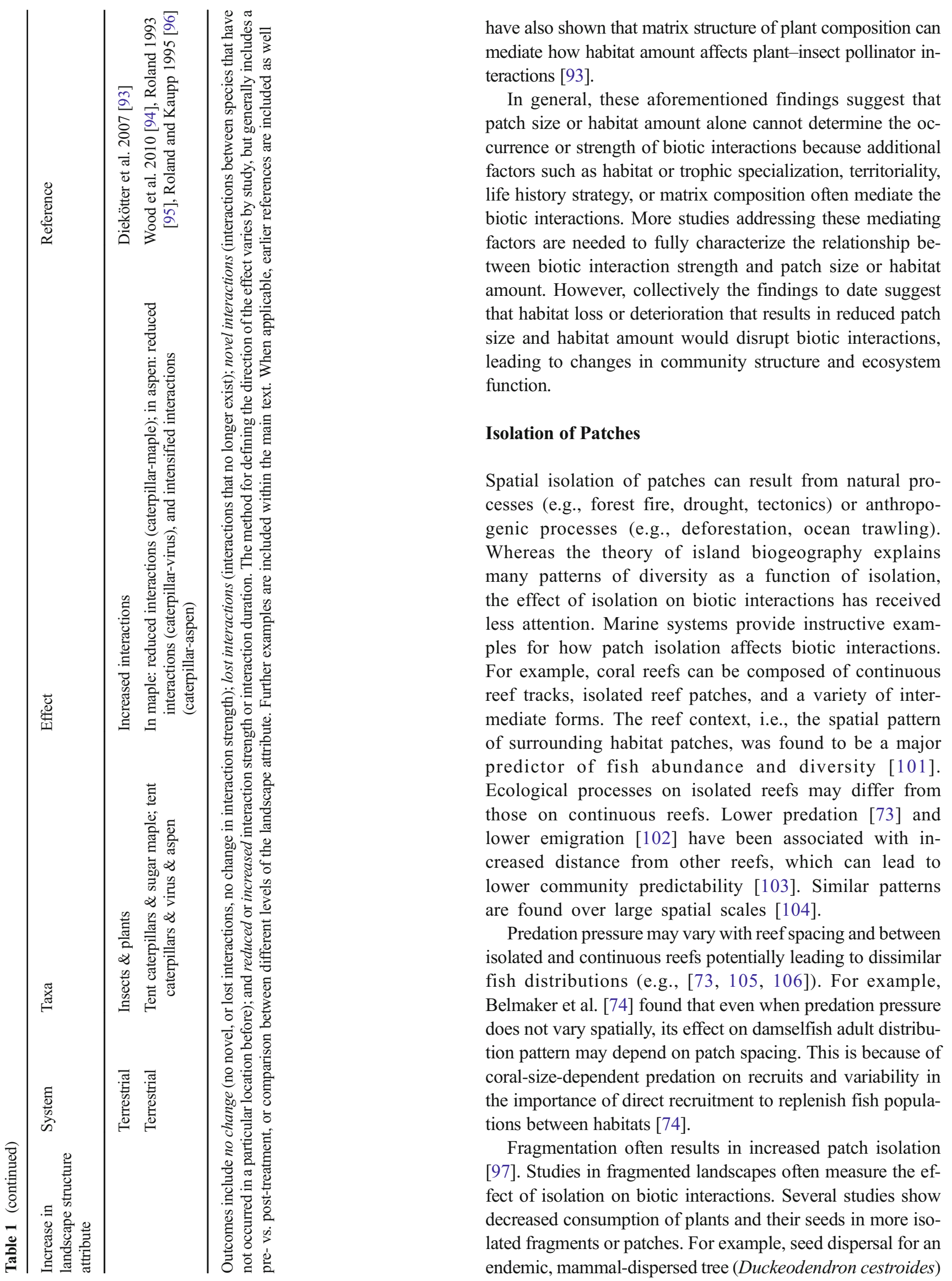


was far lower in forest fragments, with just approximately $5 \%$ of the number of seeds being dispersed further than $10 \mathrm{~m}$ away from parent trees than in intact forests [107]. Leaf herbivory in the Amazon can also be reduced in isolated fragments, possibly because of lower immigration of insect herbivores [108]. Similar relationships were found in a landscape-scale fragmentation experiment of understory plants in a longleaf pine savanna that controlled for potential confounding effects of isolation, the ratio of edge to area, and edge proximity through its arrangement of landscape structure [64]. Increased patch isolation associated with decreased levels of herbivory for two of five plant species (the perennial bunchgrass Sorghastrum secundum and the perennial forb Carphephorus bellidifolius). However, there were no effects of isolation on pollination rates or pre-dispersal seed predation.

Increasing isolation can stabilize predator-prey interactions [36], but the differential responses to habitat isolation between host species and their natural enemies can change the strength of the interaction. For example, isolation of woody habitats reduced species richness and abundance of both parasitoids and their hosts, wasps and bees, in the Swiss plateau [75]. However, the reduction for the parasitoids was greater than that for the hosts, leading to a reduction in parasitism rates. Isolation can also affect trophic levels differently, and thus change the structure and function of food webs $[109,110]$. For instance, more isolated headwater streams had a higher diversity of predatory macroinvertebrates than more highly connected mainstem streams, but this effect was reversed for herbivorous macroinvertebrates [71]. Additionally, shallow isolated lakes are frequently fishless: the absence of these top predators allows plant, invertebrate, amphibian, and bird communities to proliferate [72].

\section{Barriers to Dispersal and Movement}

Whereas isolation is a multi-patch phenomenon that is dictated by the interaction of the patch and the matrix (e.g., patchcorridor-matrix model of landscape structure; [57]), barriers to movement (as presented in Fig. 1) are a within-patch phenomenon that physically restricts movements within or outside the patch. Movement within a landscape can affect important interactions among species including resource acquisition, evading enemies (predators and competitors), and mutualisms. Hence the placement, size, and duration of barriers can set the stage for enabling or deterring the occurrence of certain species, making it difficult for certain interactions to occur, while promoting others [111].

Both natural (e.g., waterfalls) and anthropogenic (e.g., dams) barriers can alter biotic interactions in freshwater systems. For example, populations of native salmonids in headwater streams can be displaced by non-native salmonids via competition and predation $[76,112]$. This has led to some debate about leaving barriers in place or even adding them to the landscape to protect native fishes [76, 113]. In one case, the removal of a dam in Wisconsin, USA, resulted in increased competition and more intense predation from previously absent species in stream fish communities [77]. Given their importance to fish distribution, barriers and network structure should be explicitly included in models of fish community structure to determine the best conservation value for taxonomic, functional, and phylogenetic aspects of diversity [114]. Models incorporating these aspects showed that most watersheds ranked as being high conservation value were spatially restricted, reflecting the lack of widespread connectivity for mobile fishes [114]. If anthropogenic fragmentation is severe, biotic interactions may have little impact on diversity. In an assessment of streams in Kansas, USA, segment fragmentation by roads yielded lower alpha fish species diversity and higher beta fish species diversity compared with segments maintaining high connectivity, regardless of hydrologic stability [115].

Some barriers may reduce or omit biotic interactions if the barrier has a similar effect on the interacting species. Although barriers and boundaries in marine systems are not as visible as in freshwater or terrestrial systems, they can still strongly mediate species' occurrence [116]. For example, on the central south coast of England, species boundaries occur because of poor rock substrate, topography, and oceanographic conditions that make it difficult for larval recruits to settle and survive [78]. A suspected interaction between two barnacles (Chthamalus montagui and Semibalanus balanoides) [117] is unlikely to be strong beyond the species boundary, because neither species can successfully disperse in high enough numbers $[78,118]$. On the other hand, some barriers may intensify interactions. In coastal Antarctica, extensive sea ice or blockage by icebergs during five consecutive years altered usual migration patterns of Adelie penguin (Pygoscelis adeliae) across colonies, and increased foraging intensity at the largest colony as a result of increased competition among individuals [79].

Species requiring large home ranges can be especially affected by barriers to movement. For example, the decline of caribou (Rangifer tarandus) in boreal forests has been linked to the presence of road networks, seismic lines, and other linear features that create barriers to movement and promote predation [81]. Black bears (Ursus americanus) prey on caribou and use seismic lines in boreal forests more frequently than the forest interior [82], suggesting that there are interactions between human-created barriers and predator-prey interactions.

Barriers can be ameliorated through several processes, including human-aided transport as with invasive species or assisted migration. In addition, the combination of thermal range limits and the range of interacting species can form barriers to species occurrence. Climate change is shifting those barriers [119-121]. For example, climate warming has 
enabled the mountain pine beetle (Dendroctonus ponderosae) to expand its range into new areas where temperatures are now suitable. This range expansion has also resulted in higher beetle reproductive rates on lodgepole pine (Pinus contorta) that previously had little beetle attack [122], and even attack of a novel host species - jack pine (P. banksiana) [123]. Warming and shifts in host plant abundance have also expanded the range of the Brown Argus butterfly (Aricia agestis) in Britain [124], and led to a concurrent decline in parasitism in its new range, consistent with the enemy-release hypothesis [80]. This reduction in parasitism occurred despite the existence of the parasite association with an alternate host, the Common Blue butterfly (Polyommatus icarus).

\section{Persistence of Landscape Structure}

Landscape structure can change through time and thus affect the occurrence of interacting species and their community composition. A number of freshwater ponds and streams are ephemeral or intermittent, which alters connectivity and habitat size, with consequences for species with varying reliance on water (e.g., amphibians, invertebrates) $[125,126]$. For instance, severe drought extirpated top predators in desert streams in Arizona, USA, allowing mesopredators to increase through release from competition [83]. Drought also had strong effects on fish assemblages in the Verde River in Arizona, with a decoupling of interactions between native and non-native species [84]. Species diversity can also be affected jointly by the stability of habitat and biotic interactions; in periods of hydrologic stability (stream permanence), predation is expected to be more important than environmental factors in structuring the community composition [127].

Long-term perspectives on human land-use illustrate how modifications of landscape structure can influence the occurrence of interacting species. For instance, the New England landscape in the northeastern USA experienced drastic changes over the past 400 years as it transitioned from largely forested prior to European settlement to deforested at the height of agriculture in the region (1830-1885) to largely reforested in the 1950s following the abandonment of agriculture [128]. These changes in New England's landscape structure over time impacted bird assemblages with increases in open-land species through the peak of agriculture followed by their decline with reforestation (e.g., grassland bird species: meadowlark (Sturnella magna) and bobolink (Dolichonyx oryzivorus)) [87]. Changes in large mammal abundances also coincided with changes in landscape structure in New England over this period, but given changes in attitudes towards hunting and trapping over time it is more difficult to disentangle effects of landscape structure alone [87]. After a more than 200-year absence, Alces alces (moose) have returned to southern New England and increased in abundance as forests in the region have regenerated and matured [129]. At Harvard Forest in
Massachusetts in hardwood and eastern hemlock (Tsuga canadensis) stands disturbed by logging and an invasive insect (i.e., hemlock woolly adelgid, Adelges tsugae), additive effects of deer and moose browsing, compared to deer browsing alone, resulted in delayed recruitment of trees and a greater abundance of disturbance-specialist herbs 4-7 years postdisturbance [130].

As the climate changes, so too will the structure of landscapes. This can lead to spatial mismatches and new matches between species (i.e., no-analog communities sensu [120]). Quaternary paleoecological records provide ample evidence of historical no-analog fossil communities across taxa (e.g., plants, mammals, coleopterans, mollusks, foraminifera; reviewed by Williams and Jackson [120]). Novel and lost interactions were commonplace during past changes in climate and resulted in the reshuffling of community composition [131]. Looking forward, as individual species respond to changing climate and landscape structure, rare interactions could become more common, and completely novel interactions are likely to emerge.

The Arctic is the fastest-warming region of the planet [132, 133], and associated changes in the timing and duration of landscape structure are already affecting biotic interactions. For example, migrating caribou (Rangifer tarandus) in Greenland are not keeping pace with early-onset spring and are often unable to reach their calving grounds in time to catch the earlier peak forage; this trophic mismatch leads to a decline in fecundity and an increase in calf mortality [88]. Associated field experimental results show a destabilization and decreased diversity when these large herbivores are removed under warming conditions [134]. In addition, warming conditions and melting sea ice are associated with polar bears (Ursus maritimus) spending less time on ice hunting ringed seals (Pusa hispida), and more reliance on land-based snow geese (Chen caerulescens) eggs ([85] and references therein). The earlier onset of sea ice breakup is also expected to shorten the 2-month time frame between peak ice-dependent algal blooms that are essential for fueling key Arctic grazer's reproduction and peak open-ocean phytoplankton blooms that are essential for the grazer's offspring development [86]. Shortening the time frame between these two peaks could lead to mismatch between essential food resources and the reproductive cycle of key Arctic grazers [86].

\section{Landscape Complexity}

Landscape complexity, including the number of different habitat types, the prevalence of edge habitat, and the configuration of habitat, can affect the number and strength of interactions in different ways. Some studies find that increasing complexity yields either more interactions or stronger interactions, while other studies find that increasing complexity yields reduced interactions or no change. For example, in an experiment 
manipulating seafloor habitat complexity, in habitat with more substrate heterogeneity and more physical structure, survival of red king crab (Paralithodes camtschaticus) increased and attack rates by predatory Pacific halibut (Hippoglossus stenolepis) decreased [135]. In contrast, in Florida Key coral reefs with more habitat complexity, risk of predators had a stronger negative effect on fish herbivory and also altered their size structure [91]. In a predation experiment with lobsters off the Rhode Island coast, those in or closest to cobble refuge patches had the highest survival in the short term, whereas this relationship switched later on in the experiment for some sites, potentially as a result of the use of adjacent refuge in seagrass beds [136]. Distance to edge can also have little or no effect on biotic interactions. For example, in a predator caging experiment that manipulated distance from patch edge and complexity of eelgrass (Zostera marina) bed structure, closer proximity to edge habitat yielded higher epifauna (prey) abundances as a whole, regardless of bed complexity, even though some amphipods were more abundant in interiors [92]. However, there was no evidence that predation was also higher closer to the habitat edge, and no difference in predator diet from edge to interior.

The structural complexity of freshwater ecosystems can significantly influence biotic interactions. In particular, river systems resemble dendritic branching networks, which can affect species dispersal, energy flow, population dynamics, and community diversity [137]. Increasing dendritic spatial complexity using fractal models resulted in reduced interaction rates, reproduction, and predation in a predator-prey model [138]; predators can get stuck in branches with depleted resources, highlighting the influence of geometry and complexity. Tributary junctions can serve as biological hotspots for abundance and richness ([139-141], but see [142]). Increasing spatial complexity in a riverine floodplain in Washington, USA, resulted in decreased interaction strength between predators and prey because the prey could find refuge in the more complex landscape [90]. Similarly, it is likely that complexity within an experimental dendritic network enabled protists to avoid competition by dispersing through the network, which resulted in increased community evenness [143]. Differences in lake connectivity at landscape scales can also affect biotic interactions. Lake regions comprise a combination of isolated seepage lakes and more connected drainage lakes. Fish community composition in lake regions can be strongly influenced by landscape structure: in Arctic Alaska, the dominant competitor, lake trout (Salvelinus namaycush), only naturally occurs in well-connected lakes. It is likely that arctic char (Salvelinus alpinus) have been able to dominate in some isolated lakes because they are landlocked, relict populations that are inaccessible to competitive lake trout [89].

Habitat edges in particular can influence biotic interactions in multiple ways [144]. Edges may form a barrier to species movement and dispersal and thus affect biotic interactions as discussed earlier (see "Barriers to Dispersal and Movement"). Edges may also have differential influences on species' populations, and thus change the intensity of outcomes of biotic interactions. For example, microclimates may vary greatly across edges and the microclimatic difference can change relative competitiveness of different species and even alter successional patterns in fragmented rain forests by differentially influencing species' mortality [145]. Similarly, increased UV radiation at forest edges in Ontario, Canada likely caused higher mortality of the nuclear polyhedrosis virus, a natural enemy of tent caterpillars (Malacosoma disstria). Therefore, a longer duration of tent caterpillar outbreaks is associated with increased edge density in aspen poplar (Populus tremuloides)dominated North American forest landscapes [95, 96]. However, this relationship does not hold across all portions of the caterpillar's range and may differ by host tree species. Studies in sugar maple (Acer saccharum)-dominated forests in the northeastern USA revealed the opposite effect, where forests with increasing forest cover and decreasing forest edge had longer outbreak duration [94].

Proximity to edge and the associated influence of surrounding matrix can also affect the outcome of biotic interactions. In a landscape-scale fragmentation experiment, Brudvig et al. [64] found that decreased pre-dispersal seed predation only associated with decreased edge proximity for one understory bunchgrass (Anthaenantia villosa). On the other hand, pollination rates on understory plants did not differ by patch and matrix arrangement [64]. Simulation models showed that proximity to the matrix edge can influence Allee effects and rates of predation by matrix-sourced nest predators, but if bird nest habitat patches are large enough, these effects can be ameliorated [146]. Field experiments show that visitation by pollinators is significantly higher in clover patches surrounded by bare ground than in those surrounded by grass [93]. In addition, the effect of matrix can propagate across trophic levels. The higher pollinator visitation led to a higher seed set of clover and in turn resulted in higher abundances of seed predators and their parasitoids.

\section{Effects of Biotic Interactions on Landscape Structure}

Whereas most studies focus on the influence of landscape structure on biotic interactions, biotic interactions can also have profound effects on landscape structure [1], including landscape complexity, extent of habitat, and the structure of landscape features. Interactions involving foundation species (i.e., single common species that control ecosystem processes and community composition [2]) and ecosystem engineers [147] provide particularly good examples of this interplay.

Biotic interactions that influence foundation species are especially likely to alter landscape structure. In eastern forests of the USA, eastern hemlock (Tsuga canadensis) is a foundation species $[2,148]$. The acidic litter and deep shade cast by 
hemlock creates a sparse forest understory with unique microclimatic conditions and soil biota relative to surrounding deciduous hardwood forests [149, 150]. The hemlock woolly adelgid (HWA; Adelges tsugae) is an aphid-like insect from Asia that is invasive within the range of eastern hemlock, can kill all age classes of hemlock trees [151], and is causing largescale mortality across much of the eastern USA [148]. With the decline of hemlock in response to HWA infestation and the conversion of hemlock stands into structurally different deciduous canopies (i.e., primarily black birch (Betula lenta) in the northeast and rhododendron (Rhododendron maximum) in the southeast [2]), eastern forests are becoming more homogeneous at the landscape scale as they shift from coniferous to deciduous dominated, as conifer patches are lost.

Foundation species in coastal marine systems are vital to the structure and function of coastal marine communities (as reviewed by Angelini et al. [9]). Biotic interactions with foundation species can further promote habitat availability or reduce it. Mangroves (e.g., Rhizophora spp.) form dense stands in tropical coastal and estuarine environments acting as foundation species capable of modulating intertidal foodwebs, decreasing soil acid sulfides, and supporting inshore fisheries [2]. Mangroves cannot colonize an area if there is not already a land formation on which to establish. Buildup of organic sediment from other living organisms along with physical processes provides the lateral land formation necessary for mangroves to colonize upon [152]. Human interactions with mangroves often result in loss of available habitat (e.g., clearing of mangroves for shrimp farming and coastal development [153]).

In many cases, invasive species alter the habitat structure of other species through their dominance. For example, invasions by Ammophila beach grass species in the US Pacific Northwest removed important open-sand habitat, threatening the Western snowy plover (Charadrius alexandrinus nivosus), and causing declines in some native plants [154]. Macro-algae (Caulerpa genus) invasion of native seagrass beds in the Mediterranean Sea can affect different aspects of habitat quality for other species including reducing sediment quality [155], and altering the hydrodynamics of the sea floor, ultimately resulting in increased erosion during storms [156].

Ecosystem engineering species can alter landscape structure through their physical impact on the landscape. Beavers are particularly adept at increasing habitat heterogeneity and altering geomorphic and hydrologic templates of freshwater systems and adjacent terrestrial systems through dam building activity [157]. A recent study in restored streams in Scottish pastures found that beaver-modified hydromorphological features in streams increased nutrient availability and macroinvertebrate species diversity at the landscape scale, as compared with unmodified sections of streams [158]. Macroinvertebrate feeding guilds also shifted from grazer/ scraper and filter feeder dominant in unmodified sections to shredder and collector-gatherer dominant in beaver-modified sections [158], indicating a shift in the composition of those consumer interactions. Similar positive effects of beavermodified habitat on biodiversity have been found for fish [159] and amphibians [160].

Interactions between vegetation and sediment-especially at the aquatic-terrestrial interface - can lead to varying landscape structures including coastal dunes, braided rivers, and salt marshes [5]. Each sediment-binding plant species may have a different potential to capture sediment and create landscape features. Interactions among these species ultimately affect the composition of the plant community, and thus the structure of landscape itself. In the US Pacific Northwest, the introductions and subsequent invasions of two Ammophila beach grasses caused landscape-scale transformations of coastal dune shape [161]. This is surprising, given the dominant influence of the physical environment on coastal geomorphology [162]. Experimental mesocosms and wind tunnel experiments showed that $A$. arenaria has a superior ability to capture sand and build tall dunes, whereas $A$. breviligulata is an inferior dune builder [163]. However, stronger competition and invasion potential by A. breviligulata [164] suggests that in the future, foredunes are likely to be lower, offering less coastal protection from sea level rise and increasing wave heights [165].

Traditionally, ecologists have studied the effects of the abiotic environment (including landscape structure) on biota, including biotic interactions. More studies are needed to characterize how biotic interactions affect landscape structure, and their associated feedbacks. Combined, these studies can quantify the coupling and feedbacks between biotic interactions and landscape structure.

\section{Conclusions}

It is clear from the studies discussed herein that landscape structure and biotic interactions are inherently linked. Landscape structure mediates the outcomes of biotic interactions, and even enables or prevents specific interactions from occurring. Biotic interactions can also mediate landscape structure. This is particularly evident with ecosystem engineers. Together, landscape structure and biotic interactions can affect population sizes, distributions of species, ecosystem functioning, and species diversity.

Despite the degree to which landscape structure and biotic interactions are linked and affect species' distributions, populations, and ecosystem function, they are rarely considered when predicting future changes to species geographic ranges and populations, let alone the effects of climate change. Given their high degree of linkage, it is imperative to include both landscape structure and biotic interactions in predictive modeling frameworks. Out of 90 studies on species 
distribution models that considered climate change, only 18 studies explicitly considered realistic dispersal rates or distances (partly as a function of landscape structure), and only three studies considered biotic interactions [111]. Whereas such models including biotic interactions and landscape features may necessarily be more complex, they incorporate key aspects of species occurrence.

This review points to a basic need to better integrate ecology subfields of landscape ecology and community ecology. The metacommunity framework is an excellent starting point, yet metacommunity models and other multi-species models could include landscape structure more explicitly than they currently do. In addition, further emphasizing interactions other than competition (e.g., predation and mutualism) in the metacommunity framework (e.g., [34]) would provide a more holistic look at biotic interactions with a landscape perspective. One potentially innovative way to further integrate landscape ecology and community ecology is by exploring entire ecological networks over large spatial scales (e.g., [166]). Networks depict the flow of energy and biomass throughout an ecosystem and thus can provide a link between ecosystem functioning and landscape structure. Traditionally, ecological networks have been studied at a given location to detail the structure and dynamics of specific systems (e.g., [167-170]). As a result, exploring variation in network structure has been relegated to comparing vastly different networks, collected with different methodology [171]. A relatively new approach explores the network structure of multiple networks of the same type over large spatial extents (e.g., [166, 172]). This approach has potential for identifying drivers of change in network structure, how species' roles change within networks over space and time [173], and the assembly of local networks from networks at continental and regional scales (a.k.a., metawebs; [174]).

In relation to this need, we suggest that landscape-scale experiments will help advance our understanding of community ecology in the context of landscapes. Experiments that manipulate landscape structure in the context of biotic interactions provide important insights about their interplay (e.g., [64]). In addition, coordinated research networks of investigators working at different sites are integral for such landscapescale experiments $[175,176]$. For instance, Nutrient Network (i.e., NutNet) is a global research cooperative implementing a large cross-site experiment (nearly 100 sites) to investigate productivity-diversity relationships to ask under what conditions grazers versus fertilization control plant productivity, diversity, and biomass (www.nutnet.unm.edu). Networks with long-term dedicated governmental funding (e.g., National Ecological Observatory Network (NEON; www. neonscience.org), Long Term Ecological Research (LTER; www.lternet.edu)) provide the types of long temporal and large spatial data sets needed for addressing landscape-scale questions in community ecology $[177,178]$.
We have demonstrated that studying the interplay between landscape structure and biotic interactions yields significant insight into the fundamental processes that structure populations, communities, and ecosystems. In an era of rapid global change, these interactions are important to incorporate into the conservation and management of populations, communities, and ecosystems. We anticipate that the next major advances in the field will come from increasingly complex and coordinated landscape-level experiments that focus on the interplay between biotic interactions and landscape structure. Thus, a more cohesive integration of landscape and community ecology is critical to addressing the challenges of the twenty first century.

Acknowledgements We thank Matt Betts and Lenore Fahrig for providing the opportunity to review the connections between landscape structure and biotic interactions. We also thank two anonymous reviewers as well as Gary Roloff and Kendra Cheruvelil for helpful comments that improved this manuscript. The following funding sources provided support while writing this manuscript: National Science Foundation under Grant No. 1550765, Michigan State University (P.L. Zarnetske), University of Florida (B. Baiser), Portland State University (A. Strecker), Bryn Mawr College K.G. Research Fund (S. Record), Israel Science Foundation grant number 1356/15 (J. Belmaker), and Academia Sinica (M.-N. Tuanmu).

\section{Compliance with Ethical Standards}

Conflict of Interest On behalf of all authors, the corresponding author states that there is no conflict of interest.

Human and Animal Rights and Informed Consent This article does not contain any studies with human or animal subjects performed by any of the authors.

\section{Appendix}

Code used in Scopus search to obtain a set of studies from the last decade (2005-present) that focused on biotic interactions and landscape structure. A total of 9391 documents were included by the start of August 2016. The search was performed such that Keyword AND Title AND Abstract each contained one landscape structure term AND one biotic interaction term. The search was limited to English language articles (94.2\%), reviews $(2.9 \%)$, conference papers $(1.4 \%)$, articles in press $(1.0 \%)$, and book chapters $(0.4 \%)$. We also limited the search to Environmental Sciences (59.1\%) and Agriculture and Biological Sciences (79.7\%); some articles fit in both subject areas. In general the number of papers per year increased through time (2005: 571 studies), peaking in 2012 (968 studies).

((()(ABS (barrier OR biogeography OR "braided river*” OR "coastal protection" OR confluence OR connectivity OR corridor* OR defragmentation OR dispers* OR "species distribution*" OR "environmental gradient*" OR fragment* OR 
"edge effect" OR "geographical gradient*” OR geometry OR habitat* OR intermitten* OR "island biogeography" OR species OR isolation OR "land building" OR landscape OR "metapopulation dynamic*" OR network OR "patch dynamic*" OR "prey refuge*" OR "refugia" OR "regional process*" OR "shoreline protection" OR "space-use" OR "spatial ecology" OR "spatial heterogeneity" OR "spatial scale*" OR "spatial structure" OR "temporary-river" OR zonation OR biomorphodynamic* OR ecogeomorph*))) AND ((ABS (assemblage* OR biodiversity OR "biological invasion*" OR "biological control" OR "biotic interaction*" OR "biotic resistance" OR coexistence OR communit* OR "community composition" OR "community dynamic*" OR "community ecology" OR "community stability" OR competition OR consumer* OR diversity OR "ecological network*" OR "ecosystem engineer" OR "enemy release" OR facilitation OR "food chain" OR "food web" OR "food-web" OR "food-web structure" OR "foundation species" OR herbivor* OR "interaction strength" OR "interaction web" OR "interspecific competition" OR "interspecific interaction*" OR "keystone species" OR "mass effects" OR "multitrophic interaction" OR mutualism OR mutualist* OR "no-analog community*" OR "nursery function" OR "patch-dynamic*" OR pathogen OR pest OR pollination OR "pollination network" OR pollinator OR predation OR predator* OR prey OR "species composition" OR "species interaction" OR "species richness" OR "species sorting" OR "stress gradient hypothesis" OR symbiotic OR "top-down" OR trophic OR metacommunit*)))) AND PUBYEAR > 2004) AND ( ( ((KEY (barrier OR biogeography OR "braided river*" OR "coastal protection" OR confluence OR connectivity OR corridor* OR defragmentation OR dispers* OR "species distribution*" OR "environmental gradient*" OR fragment* OR "edge effect" OR "geographical gradient*" OR geometry OR habitat* OR intermitten* OR "island biogeography" OR species OR isolation OR "land building" OR landscape OR "metapopulation dynamic*" OR network OR "patch dynamic*" OR "prey refuge*" OR "refugia" OR "regional process*" OR "shoreline protection" OR "space-use" OR "spatial ecology" OR "spatial heterogeneity" OR "spatial scale*” OR "spatial structure" OR "temporary-river" OR zonation OR biomorphodynamic* OR ecogeomorph*))) AND ((KEY (assemblage* OR biodiversity OR "biological invasion*" OR "biological control" OR "biotic interaction*" OR "biotic resistance" OR coexistence OR communit* OR "community composition" OR "community dynamic*" OR "community ecology" OR "community stability" OR competition OR consumer* OR diversity OR "ecological network*" OR "ecosystem engineer" OR "enemy release" OR facilitation OR "food chain" OR "food web" OR "food-web" OR "food-web structure" OR "foundation species" OR herbivor* OR "interaction strength" OR "interaction web" OR "interspecific competition" OR "interspecific interaction*" OR "keystone species" OR "mass effects" OR "multitrophic interaction" OR mutualism OR mutualist* OR "no-analog community*” OR "nursery function" OR "patchdynamic*" OR pathogen OR pest OR pollination OR "pollination network" OR pollinator OR predation OR predator* OR prey OR "species composition" OR "species interaction" OR "species richness" OR "species sorting" OR "stress gradient hypothesis" OR symbiotic OR "top-down" OR trophic OR metacommunit*)))) AND PUBYEAR > 2004) AND ((((TITLE (barrier OR biogeography OR "braided river*" OR "coastal protection" OR confluence OR connectivity OR corridor* OR defragmentation OR dispers* OR "species distribution*" OR "environmental gradient*" OR fragment* OR "edge effect" OR "geographical gradient*" OR geometry OR habitat* OR intermitten* OR "island biogeography" OR species OR isolation OR "land building" OR landscape OR "metapopulation dynamic*" OR network OR "patch dynamic*" OR "prey refuge*" OR "refugia" OR "regional process*" OR "shoreline protection" OR "space-use" OR "spatial ecology" OR "spatial heterogeneity" OR "spatial scale*" OR "spatial structure" OR "temporary-river" OR zonation OR biomorphodynamic* OR ecogeomorph*))) AND ((TITLE (assemblage* OR biodiversity OR "biological invasion*" OR "biological control" OR "biotic interaction*" OR "biotic resistance" OR coexistence OR communit* OR "community composition" OR "community dynamic*" OR "community ecology" OR "community stability" OR competition OR consumer* OR diversity OR "ecological network*" OR "ecosystem engineer" OR "enemy release" OR facilitation OR "food chain" OR "food web" OR "food-web" OR "food-web structure" OR "foundation species" OR herbivor* OR "interaction strength" OR "interaction web" OR "interspecific competition" OR "interspecific interaction*" OR "keystone species" OR "mass effects" OR "multitrophic interaction" OR mutualism OR mutualist* OR "no-analog community*” OR "nursery function" OR "patch-dynamic*" OR pathogen OR pest OR pollination OR "pollination network" OR pollinator OR predation OR predator* OR prey OR "species composition" OR "species interaction" OR "species richness" OR "species sorting" OR "stress gradient hypothesis" OR symbiotic OR "top-down" OR trophic OR metacommunit*)))) AND P U B Y E A R > 2004 ) ) ) A N D ( L I M I T T O ( S U B J A R E A, " A G R I") O R L IM I T T O ( S U B J A R E A, " E N V I ”)) A N D (EX C L U D E ( S U B J A R E A, "B I O C”) OR EX C L U DE ( S U B J A R E A, “M E D I") OR EX C L U DE ( S U B J A R E A, “IMMU”) O R EX C L U D E ( S U B J A R E A, “E A R T") O R EX C L U D E ( S U B J A R E A, “PHAR") O R EX C L U DE ( S U B J A R E A, "C H E M") O R E X C L U D E ( S U B J A R E A, "S O C I") O R EX C L U DE ( S U B J A R E A, “M A T H") O R EX C L U D E ( S U B J A R E A, "C EN G") O R EX C L U D E ( S U B J A R E A, “NEUR”) OR 
E X C L U D E ( S U B J A R E A , “E N G I ”) O R E X C L U D E ( S U B J A R E A , “C O M P") O R E X C L U D E ( S U B J A R E A , “V E T E”) O R E X C L U D E ( S U B J A R E A , “E N E R") O R E X C L U D E ( S U B J A R E A, “D E C I ”) O R E X C L U D E ( S U B J A R E A " "E C O N") O R E X C L U D E ( S U B J A R E A, “M A T E”) O R E X C L U D E ( S U B J A R E A , “A R T S”) O R E X C L U D E ( S U B J A R E A, "P H Y S”) O R E X C L U D E ( S U B J A R E A, “B U S I ”) O R E X C L U D E ( S U B J A R E A, “N U R S ”) O R E X C L U D E ( S U B J A R E A , “P S Y C”) O R E X C L U D E ( S U B J A R E A, “H E A L”) O R E X C L U D E ( S U B J A R E A , “M U L T") O R EXCLUDE(SUBJAREA, “DENT”)) AND (LIMITT O ( L A N G U G E, “English”) ) A N D ( E X C L U D E ( D O C T Y P E, “n o") O R E X C L U D E ( D O C T Y P E, “ 1 e ”) O R E X C L U D E ( D O C T Y P E, “ e d" ) O R EXCLUDE(DOCTYPE,"sh”))

\section{References}

1. Turner MG. Landscape ecology: what is the state of the science? Annu Rev Ecol Evol Syst. 2005;36:319-44.

2. Ellison AM, Bank MS, Clinton BD, Colburn EA, Elliott K, Ford $\mathrm{CR}$, et al. Loss of foundation species: consequences for the structure and dynamics of forested ecosystems. Front Ecol Environ. 2005;3:479-86.

3. Hastings A, Byers JE, Crooks JA, Cuddington K, Jones CG, Lambrinos JG, et al. Ecosystem engineering in space and time. Ecol Lett. 2007;10:153-64.

4. Foley JA, DeFries R, Asner GP, Barford C, Bonan G, Carpenter SR, et al. Global consequences of land use. Science. 2005;309:570-4.

5. Murray AB, Knaapen MAF, Tal M, Kirwan ML. Biomorphodynamics: physical-biological feedbacks that shape landscapes. Water Resour. Res. 2008;44.

6. Leibold MA, Holyoak M, Mouquet N, Amarasekare P, Chase JM, Hoopes MF, et al. The metacommunity concept: a framework for multi-scale community ecology. Ecol Lett. 2004;7:601-13.

7. Belmaker J, Zarnetske P, Tuanmu M-N, Zonneveld S, Record S, Strecker A, et al. Empirical evidence for the scale dependence of biotic interactions. Glob Ecol Biogeogr. 2015;24:750-61.

8. Thuiller W, Pollock LJ, Gueguen M, Münkemüller T. From species distributions to meta-communities. Ecol Lett. 2015;18:1321-8.

9. Angelini C, Altieri AH, Silliman BR, Bertness MD. Interactions among foundation species and their consequences for community organization, biodiversity, and conservation. Bioscience. 2011;61: $782-9$.

10. Grinnell J. Field tests of theories concerning distributional control. Am Nat. 1917;51:115-28.

11. Elton C. Animal ecology. University of Chicago Press, New York. 1927. http:/www.press.uchicago.edu/ucp/books/book/chicago/A/ bo25281897.html. Accessed 19 Jul 2016.

12. Hutchinson GE. Concluding remarks. Cold Spring Harb Symp Quant Biol. 1957;22:415-27.

13. Hutchinson GE. Limnological studies in Connecticut. VII. A critical examination of the supposed relationship between phytoplakton periodicity and chemical changes in lake waters. Ecology. 1944;25:3-26.

14. Holt RD. Bringing the hutchinsonian niche into the 21 st century: ecological and evolutionary perspectives. Proc Natl Acad Sci. 2009;106:19659-65.

15. Bruno JF, Stachowicz JJ, Bertness MD. Inclusion of facilitation into ecological theory. Trends Ecol Evol. 2003;18:119-25.

16. Guisan A, Thuiller W. Predicting species distribution: offering more than simple habitat models. Ecol Lett. 2005;8:993-1009.

17. Soberón J. Grinnellian and Eltonian niches and geographic distributions of species. Ecol Lett. 2007;10:1115-23.

18. Araújo MB, Luoto M. The importance of biotic interactions for modelling species distributions under climate change. Glob Ecol Biogeogr. 2007;16:743-53.

19. Zarnetske PL, Skelly DK, Urban MC. Biotic multipliers of climate change. Science. 2012;336:1516-8.

20. Wisz MS, Pottier J, Kissling WD, Pellissier L, Lenoir J, Damgaard $\mathrm{CF}$, et al. The role of biotic interactions in shaping distributions and realised assemblages of species: implications for species distribution modelling. Biol Rev. 2013;88:15-30.

21. MacArthur RH, Wilson EO. The theory of island biogeography. Princeton: Princeton University Press; 1967.

22. Simberloff DS, Wilson EO. Experimental zoogeography of islands: the colonization of empty islands. Ecology. 1969;50:278-96.

23. Brown JH. Mammals on mountaintops: nonequilibrium insular biogeography. Am Nat. 1971;105:467-78.

24. Whitcomb BL, Whitcomb RF, Bystrak D. Island biogeography and "Habitat Islands" of eastern forest. III. Long-term turnover and effects of selective logging on the avifauna of forest fragments. Am Birds. 1977;31:7.

25. Rybicki J, Hanski I. Species-area relationships and extinctions caused by habitat loss and fragmentation. Ecol Lett. 2013;16:27-38.

26. Diamond JM. Island biogeography and conservation: strategy and limitations. Science. 1976;193:1027-9.

27. Holt RD. Temporal and spatial aspects of food web structure and dynamics. In: Polis GA, Winemiller KO, editors. Food webs. Springer, New York. 1996. p. 255-7. doi:10.1007/978-1-46157007-3_25.

28. Gravel D, Massol F, Canard E, Mouillot D, Mouquet N. Trophic theory of island biogeography. Ecol Lett. 2011;14:1010-6.

29. Cirtwill AR, Stouffer DB. Knowledge of predator-prey interactions improves predictions of immigration and extinction in island biogeography. Glob Ecol Biogeogr. 2015. doi:10.1111/geb.12332.

30. Piechnik DA, Lawler SP, Martinez ND. Food-web assembly during a classic biogeographic study: species' "trophic breadth" corresponds to colonization order. Oikos. 2008;117:665-74.

31. Logue JB, Mouquet N, Peter H, Hillebrand H. Empirical approaches to metacommunities: a review and comparison with theory. Trends Ecol Evol. 2011;26:482-91.

32. Holt RD, Hoopes MF. Food web dynamics in a metacommunity context. In: Holyoak M, Leibold MA, Holt RD, editors. Metacommunities: spatial dynamics ecological communities. Chicago: University of Chicago Press; 2005. p. 68-93.

33. Gravel D, Canard E, Guichard F, Mouquet N. Persistence increases with diversity and connectance in trophic metacommunities. PLoS One. 2011;6:e19374.

34. Baiser B, Buckley HL, Gotelli NJ, Ellison AM. Predicting food-web structure with metacommunity models. Oikos. 2013;122:492-506.

35. Gilarranz LJ, Sabatino M, Aizen MA, Bascompte J. Hot spots of mutualistic networks. J Anim Ecol. 2015;84:407-13.

36. Huffaker CB. Experimental studies on predation: dispersion factors and predator-prey oscillations. Hilgardia. 1958;27:343-83.

37. Cooper JK, Li J, Montagnes DJS. Intermediate fragmentation per se provides stable predator-prey metapopulation dynamics. Ecol Lett. 2012;15:856-63. 
38. Burgett AA, Chase JM. Landscape context influences the abundance of amphibians and the strength of their food web interactions in small ponds. Oikos. 2015;124:629-38.

39. Hol FJH, Rotem O, Jurkevitch E, Dekker C, Koster DA. Bacterial predator-prey dynamics in microscale patchy landscapes. Proc R Soc B. 2016;283:20152154.

40. Leibold MA, Loeuille N. Species sorting and patch dynamics in harlequin metacommunities affect the relative importance of environment and space. Ecology. 2015;96:3227-33.

41. Shmida A, Wilson MV. Biological determinants of species diversity. J Biogeogr. 1985;12:1-20.

42. Hubbell SP. The unified neutral theory of biodiversity and biogeography (MPB-32). Princeton: Princeton University Press; 2001.

43. Bell G. Neutral macroecology. Science. 2001;293:2413-8.

44. Biswas SR, Wagner HH. Landscape contrast: a solution to hidden assumptions in the metacommunity concept? Landsc Ecol. 2012;27:621-31.

45. Fournier B, Mouquet N, Leibold MA, Gravel D. An integrative framework of coexistence mechanisms in competitive metacommunities. Ecography. 2016. doi:10.1111/ecog.02137.

46. Grönroos M, Heino J, Siqueira T, Landeiro VL, Kotanen J, Bini LM. Metacommunity structuring in stream networks: roles of dispersal mode, distance type, and regional environmental context. Ecol Evol. 2013;3:4473-87.

47. Jacobson B, Peres-Neto PR. Quantifying and disentangling dispersal in metacommunities: how close have we come? How far is there to go? Landsc Ecol. 2009;25:495-507.

48. Baguette M, Dyck HV. Landscape connectivity and animal behavior: functional grain as a key determinant for dispersal. Landsc Ecol. 2007;22:1117-29.

49. Betts MG, Fahrig L, Hadley AS, Halstead KE, Bowman J, Robinson WD, et al. A species-centered approach for uncovering generalities in organism responses to habitat loss and fragmentation. Ecography. 2014;37:517-27.

50. Carrara F, Altermatt F, Rodriguez-Iturbe I, Rinaldo A. Dendritic connectivity controls biodiversity patterns in experimental metacommunities. Proc Natl Acad Sci. 2012;109:5761-6.

51. Altermatt F, Schreiber S, Holyoak M. Interactive effects of disturbance and dispersal directionality on species richness and composition in metacommunities. Ecology. 2010;92:859-70.

52. Altermatt F, Holyoak M. Spatial clustering of habitat structure effects patterns of community composition and diversity. Ecology. 2012;93:1125-33.

53. Ryberg WA, Fitzgerald LA. Landscape composition, not connectivity, determines metacommunity structure across multiple scales. Ecography. 2015. doi:10.1111/ecog.01321.

54. Vanoverbeke J, Urban MC, De Meester L. Community assembly is a race between immigration and adaptation: eco-evolutionary interactions across spatial scales. Ecography. 2015. doi:10.1111/ecog.01394.

55. De Meester L, Gómez A, Okamura B, Schwenk K. The monopolization hypothesis and the dispersal-gene flow paradox in aquatic organisms. Acta Oecol. 2002;23:121-35.

56. Dayan T, Simberloff D. Ecological and community-wide character displacement: the next generation. Ecol Lett. 2005;8:875-94.

57. Forman RTT. Some general principles of landscape and regional ecology. Landsc Ecol. 1995;10:133-42.

58. Fischer J, Lindenmayer DB. Landscape modification and habitat fragmentation: a synthesis. Glob Ecol Biogeogr. 2007;16:265-80.

59. Didham RK, Kapos V, Ewers RM. Rethinking the conceptual foundations of habitat fragmentation research. Oikos. 2012;121:161-70.

60. McIntyre S, Hobbs R. A framework for conceptualizing human effects on landscapes and its relevance to management and research models. Conserv Biol. 1999;13:1282-92.

61. Fischer J, Lindenmayer DB. Beyond fragmentation: the continuum model for fauna research and conservation in human-modified landscapes. Oikos. 2006;112:473-80.
62. Lortie CJ, Brooker RW, Choler P, Kikvidze Z, Michalet R, Pugnaire FI, et al. Rethinking plant community theory. Oikos. 2004;107:433-8.

63. Hadley AS, Betts MG. The effects of landscape fragmentation on pollination dynamics: absence of evidence not evidence of absence. Biol Rev. 2012;87:526-44.

64. Brudvig LA, Damschen EI, Haddad NM, Levey DJ, Tewksbury JJ. The influence of habitat fragmentation on multiple plant-animal interactions and plant reproduction. Ecology. 2015;96:2669-78.

65. McNeely C, Power ME. Spatial variation in caddisfly grazing regimes within a northern California watershed. Ecology. 2007;88:2609-19.

66. McHugh PA, Thompson RM, Greig HS, Warburton HJ, McIntosh AR. Habitat size influences food web structure in drying streams. Ecography. 2015;38:700-12.

67. Stier AC, Hanson KM, Holbrook SJ, Schmitt RJ, Brooks AJ. Predation and landscape characteristics independently affect reef fish community organization. Ecology. 2014;95:1294-307.

68. Hattori A, Shibuno T. The effect of patch reef size on fish species richness in a shallow coral reef shore zone where territorial herbivores are abundant. Ecol Res. 2009;25:457-68.

69. Sugiura S. Species interactions-area relationships: biological invasions and network structure in relation to island area. Proc. R. Soc. Lond. B Biol. Sci. 2010;rspb20092086.

70. Trøjelsgaard K, Olesen JM. Macroecology of pollination networks. Glob Ecol Biogeogr. 2013;22:149-62.

71. Swan CM, Brown BL. Using rarity to infer how dendritic network structure shapes biodiversity in riverine communities. Ecography. 2014;37:993-1001.

72. Scheffer M, Van Geest GJ, Zimmer K, Jeppesen E, Søndergaard $\mathrm{M}$, Butler MG, et al. Small habitat size and isolation can promote species richness: second-order effects on biodiversity in shallow lakes and ponds. Oikos. 2006;112:227-31.

73. Belmaker J, Shashar N, Ziv Y. Effects of small-scale isolation and predation on fish diversity on experimental reefs. Mar Ecol Prog Ser. 2005;289:273-83.

74. Belmaker J, Ziv Y, Shashar N. Habitat patchiness and predation modify the distribution of a coral-dwelling damselfish. Mar Biol. 2008; 156:447-54.

75. Schüepp C, Herrmann JD, Herzog F, Schmidt-Entling MH. Differential effects of habitat isolation and landscape composition on wasps, bees, and their enemies. Oecologia. 2010;165:713-21.

76. Fausch KD, Rieman BE, Dunham JB, Young MK, Peterson DP. Invasion versus isolation: trade-offs in managing native salmonids with barriers to upstream movement. Conserv Biol. 2009;23:859-70.

77. Kornis MS, Weidel BC, Powers SM, Diebel MW, Cline TJ, Fox $\mathrm{JM}$, et al. Fish community dynamics following dam removal in a fragmented agricultural stream. Aquat Sci. 2015;77:465-80.

78. Herbert RJH, Southward AJ, Clarke RT, Sheader M, Hawkins SJ. Persistent border: an analysis of the geographic boundary of an intertidal species. Mar Ecol Prog Ser. 2009;379:135-50.

79. Dugger KM, Ainley DG, Lyver PO, Barton K, Ballard G. Survival differences and the effect of environmental instability on breeding dispersal in an Adélie penguin meta-population. Proc Natl Acad Sci. 2010;107:12375-80.

80. Menéndez R, González-Megías A, Lewis OT, Shaw MR, Thomas $\mathrm{CD}$. Escape from natural enemies during climate-driven range expansion: a case study. Ecol Entomol. 2008;33:413-21.

81. Festa-Bianchet M, Ray JC, Boutin S, Cote S, Gunn A. Conservation of caribou (Rangifer tarandus) in Canada: an uncertain future. Can J Zool. 2011;89:419-34.

82. Tigner J, Bayne EM, Boutin S. Black bear use of seismic lines in Northern Canada. J Wildl Manag. 2014;78:282-92.

83. Bogan MT, Lytle DA. Severe drought drives novel community trajectories in desert stream pools. Freshw Biol. 2011;56:2070-81. 
84. Ruhí A, Holmes EE, Rinne JN, Sabo JL. Anomalous droughts, not invasion, decrease persistence of native fishes in a desert river. Glob Chang Biol. 2015;21:1482-96.

85. Stirling I, Derocher AE. Effects of climate warming on polar bears: a review of the evidence. Glob Chang Biol. 2012;18: 2694-706.

86. Søreide JE, Leu E, Berge J, Graeve M, Falk-Petersen S. Timing of blooms, algal food quality and Calanus glacialis reproduction and growth in a changing Arctic. Glob Chang Biol. 2010;16:3154-63.

87. Foster DR, Aber MJD, editors. Forests in time: the environmental consequences of 1,000 years of change in New England. New Haven: Yale University Press; 2006.

88. Post E, Forchhammer MC. Climate change reduces reproductive success of an arctic herbivore through trophic mismatch. Philos Trans R Soc B Biol Sci. 2008;363:2367-73.

89. Hershey AE, Beaty S, Fortino K, Keyse M, Mou PP, O'brien WJ, et al. Effect of landscape factors on fish distribution in arctic Alaskan lakes. Freshw Biol. 2006;51:39-55.

90. Bellmore JR, Baxter CV, Connolly PJ. Spatial complexity reduces interaction strengths in the meta-food web of a river floodplain mosaic. Ecology. 2015;96:274-83.

91. Catano LB, Rojas MC, Malossi RJ, Peters JR, Heithaus MR, Fourqurean JW, et al. Reefscapes of fear: predation risk and reef hetero-geneity interact to shape herbivore foraging behaviour. J Anim Ecol. 2016;85:146-56.

92. Moore EC, Hovel KA. Relative influence of habitat complexity and proximity to patch edges on seagrass epifaunal communities. Oikos. 2010;119:1299-311.

93. Diekötter T, Haynes KJ, Mazeffa D, Crist TO. Direct and indirect effects of habitat area and matrix composition on species interactions among flower-visiting insects. Oikos. 2007;116:1588-98.

94. Wood DM, Parry D, Yanai RD, Pitel NE. Forest fragmentation and duration of forest tent caterpillar (Malacosoma disstria Hübner) outbreaks in northern hardwood forests. For Ecol Manag. 2010;260:1193-7.

95. Roland J. Large-scale forest fragmentation increases the duration of tent caterpillar outbreak. Oecologia. 1993;93:25-30.

96. Roland J, Kauppp WJ. Reduced transmission of forest tent caterpillar (Lepidoptera: lasiocampidae) nuclear polyhedrosis virus at the forest edge. Environ Entomol. 1995;24:1175-8.

97. Fahrig L. Effects of habitat fragmentation on biodiversity. Annu Rev Ecol Evol Syst. 2003;34:487-515.

98. Bregman TP, Lees AC, Seddon N, MacGregor HEA, Darski B, Aleixo A, et al. Species interactions regulate the collapse of biodiversity and ecosystem function in tropical forest fragments. Ecology. 2015;96:2692-704.

99. Petermann JS, Farjalla VF, Jocque M, Kratina P, MacDonald AAM, Marino NAC, et al. Dominant predators mediate the impact of habitat size on trophic structure in bromeliad invertebrate communities. Ecology. 2015;96:428-39.

100. Aizen MA, Sabatino M, Tylianakis JM. Specialization and rarity predict nonrandom loss of interactions from mutualist networks. Science. 2012;335:1486-9.

101. Grober-Dunsmore R, Frazer TK, Lindberg WJ, Beets J. Reef fish and habitat relationships in a Caribbean seascape: the importance of reef context. Coral Reefs. 2006;26:201-16.

102. Belmaker J, Ziv Y, Shashar N. The influence of connectivity on richness and temporal variation of reef fishes. Landsc Ecol. 2011;26:587-97.

103. Ault TR, Johnson CR. Spatial variation in fish species richness on coral reefs: habitat fragmentation and stochastic structuring processes. Oikos. 1998;82:354-64

104. Mellin C, Huchery C, Caley MJ, Meekan MG, Bradshaw CJA. Reef size and isolation determine the temporal stability of coral reef fish populations. Ecology. 2010;91:3138-45.
105. Overholtzer-Mcleod KL. Variance in reef spatial structure masks density dependence in coral-reef fish populations on natural versus artificial reefs. Mar Ecol Prog Ser. 2004;276:269-80.

106. Overholtzer-McLeod KL. Consequences of patch reef spacing for density-dependent mortality of coral-reef fishes. Ecology. 2006;87:1017-26.

107. Cramer JM, Mesquita RCG, Bentos TV, Moser B, Williamson GB. Forest fragmentation reduces seed dispersal of duckeodendron cestroides, a central Amazon endemic. Biotropica. 2007;39:709-18.

108. Fáveri SB, Vasconcelos HL, Dirzo R. Effects of Amazonian forest fragmentation on the interaction between plants, insect herbivores, and their natural enemies. J Trop Ecol. 2008;24:57-64.

109. Didham RK, Hammond PM, Lawton JH, Eggleton P, Stork NE. Beetle species responses to tropical forest fragmentation. Ecol Monogr. 1998;68:295-323.

110. Terborgh J, Lopez L, Nuñez P, Rao M, Shahabuddin G, Orihuela $\mathrm{G}$, et al. Ecological meltdown in predator-free forest fragments. Science. 2001;294:1923-6.

111. Urban MC, Zarnetske PL, Skelly DK. Moving forward: dispersal and species interactions determine biotic responses to climate change. Ann N Y Acad. Sci. 2013;1297:44-60.

112. Dunham JB, Adams SB, Schroeter R, Novinger DC. Alien invasions in aquatic ecosystems: toward an understanding of brook trout invasions and potential impacts on inland cutthroat trout in western North America. Rev Fish Biol Fish. 2002;12:19.

113. Woodford DJ, Cochrane TA, McHugh PA, McIntosh AR. Modelling spatial exclusion of a vulnerable native fish by introduced trout in rivers using landscape features: a new tool for conservation management. Aquat Conserv Mar Freshwat Ecosyst. 2011;21:484-93.

114. Strecker AL, Olden JD, Whittier JB, Paukert CP. Defining conservation priorities for freshwater fishes according to taxonomic, functional, and phylogenetic diversity. Ecol Appl. 2011;21: 3002-13.

115. Perkin JS, Gido KB. Fragmentation alters stream fish community structure in dendritic ecological networks. Ecol Appl. 2012;22: 2176-87.

116. Gaylord B, Gaines SD. Temperature or transport? Range limits in marine species mediated solely by flow. Am Nat. 2000;155:769-89.

117. Connell JH. The influence of interspecific competition and other factors on the distribution of the barnacle Chthamalus stellatus. Ecology. 1961;42:710-23.

118. Herbert RJH, Hawkins SJ. Effect of rock type on the recruitment and early mortality of the barnacle Chthamalus montagui. J Exp Mar Biol Ecol. 2006;334:96-108.

119. Parmesan C, Yohe G. A globally coherent fingerprint of climate change impacts across natural systems. Nature. 2003;421:37-42.

120. Williams JW, Jackson ST. Novel climates, no-analog communities, and ecological surprises. Front Ecol Environ. 2007;5:475-82.

121. Chen I-C, Hill JK, Ohlemüller R, Roy DB, Thomas CD. Rapid range shifts of species associated with high levels of climate warming. Science. 2011;333:1024-6.

122. Cudmore TJ, Björklund N, Carroll AL, Staffan LB. Climate change and range expansion of an aggressive bark beetle: evidence of higher beetle reproduction in naïve host tree populations. J Appl Ecol. 2010;47:1036-43.

123. Cullingham CI, Cooke JEK, Dang S, Davis CS, Cooke BJ, Coltman DW. Mountain pine beetle host-range expansion threatens the boreal forest. Mol Ecol. 2011;20:2157-71.

124. Thomas CD, Bodsworth EJ, Wilson RJ, Simmons AD, Davies ZG, Musche M, et al. Ecological and evolutionary processes at expanding range margins. Nature. 2001;411:577-81.

125. Boersma KS, Bogan MT, Henrichs BA, Lytle DA. Invertebrate assemblages of pools in arid-land streams have high functional 
redundancy and are resistant to severe drying. Freshw Biol. 2014;59:491-501.

126. Mims MC, Phillipsen IC, Lytle DA, Kirk EEH, Olden JD. Ecological strategies predict associations between aquatic and genetic connectivity for dryland amphibians. Ecology. 2014;96: 1371-82.

127. Creed RP. Predator transitions in stream communities: a model and evidence from field studies. J N Am Benthol Soc. 2006;25:533-44.

128. Thompson JR, Carpenter DN, Cogbill CV, Foster DR. Four centuries of change in northeastern United States forests. PLoS One. 2013;8:e72540.

129. Wattles DW, DeStefano S. Moose habitat in Massachusetts: assessing use at the southern edge of the range. ALCES. 2013;49:133-47.

130. Faison EK, DeStefano S, Foster DR, Plotkin AB. Functional response of ungulate browsers in disturbed eastern hemlock forests. For Ecol Manag. 2016;362:177-83.

131. Blois JL, Zarnetske PL, Fitzpatrick MC, Finnegan S. Climate change and the past, present, and future of biotic interactions. Science. 2013;341:499-504.

132. Jeffries MO, Ritchter-Menge J, Overland JE. Arctic report card 2015. 2015. http://www.arctic.noaa.gov/reportcard. Accessed 19 Jul 2016.

133. Stocker T, Dahe Q, Plattner G-K. Working group I contribution to the IPCC fifth assessment report climate change 2013: the physical science basis. Cambridge: Cambridge University Press; 2013.

134. Post E. Erosion of community diversity and stability by herbivore removal under warming. Proc R Soc B Biol Sci. 2013;280. http:// rspb.royalsocietypublishing.org/content/280/1757/20122722. Accessed 27 Oct 2013.

135. Stoner AW. Habitat-mediated survival of newly settled red king crab in the presence of a predatory fish: role of habitat complexity and heterogeneity. J Exp Mar Biol Ecol. 2009;382:54-60.

136. Selgrath JC, Hovel KA, Wahle RA. Effects of habitat edges on American lobster abundance and survival. J Exp Mar Biol Ecol. 2007;353:253-64.

137. Grant EHC, Lowe WH, Fagan WF. Living in the branches: population dynamics and ecological processes in dendritic networks. Ecol Lett. 2007;10:165-75.

138. Cuddington K, Yodzis P, DeAngelis AEDL. Predator-prey dynamics and movement in fractal environments. Am Nat. 2002;160:119-34.

139. Benda L, Poff NL, Miller D, Dunne T, Reeves G, Pess G, et al. The network dynamics hypothesis: how channel networks structure riverine habitats. Bioscience. 2004;54:413-27.

140. Osawa T, Mitsuhashi H, Ushimaru A. River confluences enhance riparian plant species diversity. Plant Ecol. 2010;209:95-108.

141. Altermatt F, Seymour M, Martinez N. River network properties shape alpha-diversity and community similarity patterns of aquatic insect communities across major drainage basins. J Biogeogr. 2013;40:2249-60.

142. Clay PA, Muehlbauer JD, Doyle MW. Effect of tributary and braided confluences on aquatic macroinvertebrate communities and geomorphology in an alpine river watershed. Freshw Sci. 2015;34:845-56.

143. Seymour M, Altermatt F. Active colonization dynamics and diversity patterns are influenced by dendritic network connectivity and species interactions. Ecol Evol. 2014;4:1243-54.

144. Fagan WF, Cantrell RS, Cosner C, Ives AEAR. How habitat edges change species interactions. Am Nat. 1999;153:165-82.

145. Janzen DH. The eternal external threat. 1986. http://agris.fao. org/agris-search/search.do?recordID=US 880692688 . Accessed 14 Nov 2015.

146. Vergara PM, Hahn I. Linking edge effects and patch size effects: importance of matrix nest predators. Ecol Model. 2009;220:1189-96.
147. Jones CG, Lawton JH, Shachak M. Organisms as ecosystem engineers. Oikos. 1994;69:373-86.

148. Ellison AM, Baiser B. Hemlock as a foundation species. Hemlock For. Giant Edge. New Haven: Yale University Press; 2014. p. 93-104.

149. Sackett TE, Record S, Bewick S, Baiser B, Sanders NJ, Ellison AM. Response of macroarthropod assemblages to the loss of hemlock (Tsuga canadensis), a foundation species. Ecosphere. 2011;2:art74.

150. Lustenhouwer MN, Nicoll L, Ellison AM. Microclimatic effects of the loss of a foundation species from New England forests. Ecosphere. 2012;3:art26.

151. Orwig DA, Foster DR, Mausel DL. Landscape patterns of hemlock decline in New England due to the introduced hemlock woolly adelgid. J Biogeogr. 2002;29:1475-87.

152. Lee SY, Primavera JH, Dahdouh-Guebas F, McKee K, Bosire JO, Cannicci $\mathrm{S}$, et al. Ecological role and services of tropical mangrove ecosystems: a reassessment. Glob Ecol Biogeogr. 2014;23:726-43.

153. Kirwan ML, Megonigal JP. Tidal wetland stability in the face of human impacts and sea-level rise. Nature. 2013;504:53-60.

154. Zarnetske PL, Seabloom EW, Hacker SD. Non-target effects of invasive species management: beachgrass, birds, and bulldozers in coastal dunes. Ecosphere. 2010;1:art13.

155. Holmer M, Marbà N, Lamote M, Duarte CM. Deterioration of sediment quality in seagrass meadows (Posidonia oceanica) invaded by macroalgae (Caulerpa sp.). Estuar Coasts. 2009;32:456-66.

156. Hendriks IE, Bouma TJ, Morris EP, Duarte CM. Effects of seagrasses and algae of the Caulerpa family on hydrodynamics and particle-trapping rates. Mar Biol. 2009;157:473-81.

157. Rosell F, Bozsér O, Collen P, Parker H. Ecological impact of beavers Castor fiber and Castor canadensis and their ability to modify ecosystems. Mammal Rev. 2005;35:248-76.

158. Law A, McLean F, Willby NJ. Habitat engineering by beaver benefits aquatic biodiversity and ecosystem processes in agricultural streams. Freshw Biol. 2016;61:486-99.

159. Smith JM, Mather ME. Beaver dams maintain fish biodiversity by increasing habitat heterogeneity throughout a low-gradient stream network. Freshw Biol. 2013;58:1523-38.

160. Cunningham JM, Calhoun AJK, Glanz WE. Pond-breeding amphibian species richness and habitat selection in a beaver-modified landscape. J Wildl Manag. 2007;71:2517-26.

161. Hacker SD, Zarnetske P, Seabloom E, Ruggiero P, Mull J, Gerrity $\mathrm{S}$, et al. Subtle differences in two non-native congeneric beach grasses significantly affect their colonization, spread, and impact. Oikos. 2012;121:138-48.

162. Zarnetske PL, Ruggiero P, Seabloom EW, Hacker SD. Coastal foredune evolution: the relative influence of vegetation and sand supply in the US Pacific Northwest. J R Soc Interface. 2015;12: 20150017.

163. Zarnetske PL, Hacker SD, Seabloom EW, Ruggiero P, Killian JR, Maddux TB, et al. Biophysical feedback mediates effects of invasive grasses on coastal dune shape. Ecology. 2012. doi:10.1890/11-1112.1.

164. Zarnetske PL, Gouhier T, Hacker SD, Seabloom EW, Bokil V. Indirect effects and facilitation among native and non-native species promote invasion success along an environmental stress gradient. J Ecol. 2013;101:905-15.

165. Seabloom E, Ruggiero P, Hacker SD, Mull J, Zarnetske P. Invasive grasses, climate change, and exposure to storm-wave overtopping in coastal dune ecosystems. Glob Change Biol. 2013;19:824-32.

166. Baiser B, Gotelli NJ, Buckley HL, Miller TE, Ellison AM. Geographic variation in network structure of a nearctic aquatic food web. Glob Ecol Biogeogr. 2012;21:579-91. 
167. Hall SJ, Raffaelli D. Food-web patterns: lessons from a speciesrich web. J Anim Ecol. 1991;60:823-41.

168. Polis GA. Complex trophic interactions in deserts: an empirical critique of food-web theory. Am Nat. 1991;138:123-55.

169. Martinez ND. Artifacts or attributes? Effects of resolution on the little rock lake food web. Ecol Monogr. 1991;61:367-92.

170. Boit A, Martinez ND, Williams RJ, Gaedke U. Mechanistic theory and modelling of complex food-web dynamics in Lake Constance. Ecol Lett. 2012;15:594-602.

171. Dunne JA. The network structure of food webs. In: Pascual M, Dunne JA, editors. Ecological networks: linking structure to dynamics in food webs. New York: OUP; 2006. p. 27-86.

172. Wood SA, Russell R, Hanson D, Williams RJ, Dunne JA. Effects of spatial scale of sampling on food web structure. Ecol Evol. 2015;5:3769-82.

173. Poisot T, Canard E, Mouillot D, Mouquet N, Gravel D. The dissimilarity of species interaction networks. Ecol Lett. 2012;15: 1353-61.
174. Baiser B, Elhesha R, Kahveci T. Motifs in the assembly of food web networks. Oikos. 2015;125:480-91.

175. Fraser LH, Henry HA, Carlyle CN, White SR, Beierkuhnlein C, Cahill JF, et al. Coordinated distributed experiments: an emerging tool for testing global hypotheses in ecology and environmental science. Front Ecol Environ. 2012;11:147-55.

176. Borer ET, Harpole WS, Adler PB, Lind EM, Orrock JL, Seabloom EW, et al. Finding generality in ecology: a model for globally distributed experiments. Methods Ecol Evol. 2013. doi:10.1111/ 2041-210X.12125.

177. Keller M, Schimel DS, Hargrove WW, Hoffman FM. A continental strategy for the national ecological observatory network. Front Ecol Environ. 2008;6:282-4.

178. Knapp AK, Smith MD, Hobbie SE, Collins SL, Fahey TJ, Hansen GJA, et al. Past, present, and future roles of long-term experiments in the LTER network. Bioscience. 2012;62:377-89. 